\title{
Impact of tropical Atlantic sea-surface temperature biases on the simulated atmospheric circulation and precipitation over the Atlantic region: An ECHAM6 model study
}

\author{
Astrid Eichhorn ${ }^{1} \cdot$ Jürgen Bader ${ }^{1,2}$
}

Received: 18 November 2015 / Accepted: 17 October 2016 / Published online: 11 November 2016

(C) The Author(s) 2016. This article is published with open access at Springerlink.com

\begin{abstract}
As many coupled atmosphere-ocean general circulation models, the coupled Earth System Model developed at the Max Planck Institute for Meteorology suffers from severe sea-surface temperature (SST) biases in the tropical Atlantic. We performed a set of SST sensitivity experiments with its atmospheric model component ECHAM6 to understand the impact of tropical Atlantic SST biases on atmospheric circulation and precipitation. The model was forced by a climatology of observed global SSTs to focus on simulated seasonal and annual mean state climate. Through the superposition of varying tropical Atlantic bias patterns extracted from the MPI-ESM on top of the control field, this study investigates the relevance of the seasonal variation and spatial structure of tropical Atlantic biases for the simulated response. Results show that the position and structure of the Intertropical Convergence Zone (ITCZ) across the Atlantic is significantly affected, exhibiting a dynamically forced shift of annual mean precipitation maximum to the east of the Atlantic basin as well as a southward shift of the oceanic rain belt. The SST-induced changes in the ITCZ in turn affect seasonal rainfall over adjacent continents. However not only the ITCZ position but also other effects arising from biases in tropical Atlantic SSTs, e.g. variations in the wind field, change the simulation of precipitation over land. The seasonal variation and spatial pattern of tropical Atlantic SST biases turns out to be crucial for the simulated atmospheric
\end{abstract}

Astrid Eichhorn

eichhorn@iau.uni-frankfurt.de

1 Max Planck Institute for Meteorology, Bundesstraße 53, 20146 Hamburg, Germany

2 Uni Climate, Uni Research and the Bjerknes Centre for Climate Research, 5007 Bergen, Norway response and is essential for analyzing the contribution of SST biases to coupled model mean state biases. Our experiments show that MPI-ESM mean-state biases in the Atlantic sector are mainly driven by SST biases in the tropical Atlantic while teleconnections from other basins seem to play a minor role.

Keywords SST bias - Tropical Atlantic - ITCZ · ECHAM6 · Warmer-get-wetter · Tropical overturning circulations

\section{Introduction}

The majority of current coupled atmosphere-ocean general circulation models (AOGCMs) suffers from substantial biases in simulating sea-surface temperatures (SSTs) in the tropical Atlantic (TA) in terms of climatological seasonal cycle and climate mean state. The most common shortcoming of these models is a warm SST bias in the south-eastern tropical Atlantic (SETA) (e.g. Fig. 1). The bias maximum often exceeds $5 \mathrm{~K}$ and is centered at the eastern boundary of the basin in the upwelling region of the NamibianAngolan coast (Richter et al. 2012a; Toniazzo and Woolnough 2014; Voldoire et al. 2014). The extension of this warm bias spreads towards the equator and covers a large fraction of the basin. Moreover, several AOGCMs simulate too cold SSTs along the coast of Venezuela and Brazil. In many cases the combination of the aforementioned erroneous SSTs leads to a reversal of the annual mean equatorial SST gradient (Davey et al. 2002; DeWitt 2005; Richter and Xie 2008).

The large-scale positive bias in the SETA as well as local biases in tropical Atlantic coastal regions constitute a long-standing problem with only little improvement over 

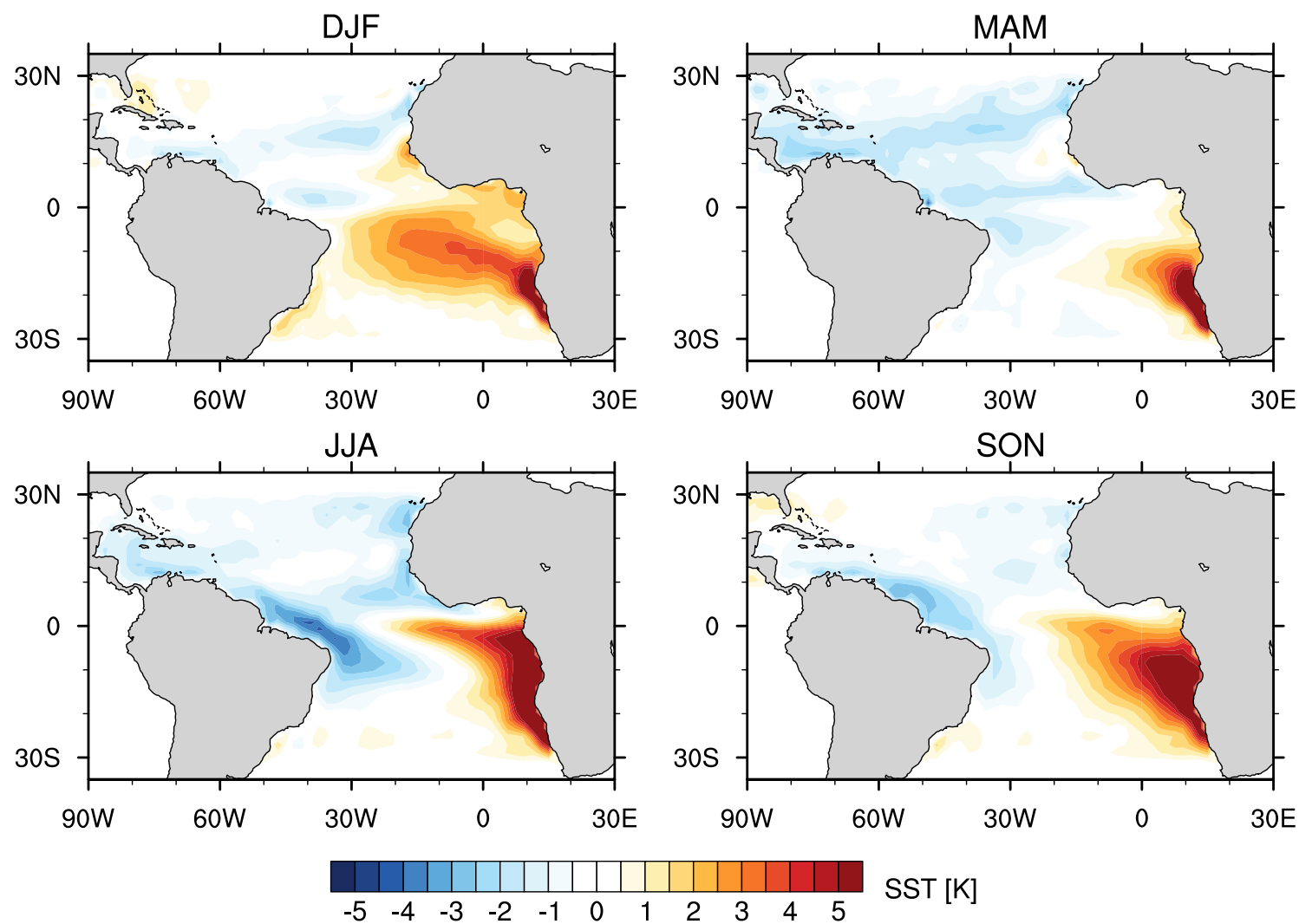

Fig. 1 The seasonal mean pattern of SST biases in the tropical Atlantic as simulated in the MPI-ESM appears as intense positive bias in the SETA, and a cool bias along the coast of Brazil. The bias pattern features a strong seasonal cycle. The bias climatology of the MPI-

the last years of model development (Richter and Xie 2008; Toniazzo and Woolnough 2014). Plenty of recent studies provide a detailed investigation of these SST biases and their interaction with other mean state model biases, hypothesizing on their origin and development but to a lesser extent dealing with their impacts on climate simulations. Approaches to solving SST-bias related problems prove to be dependent on the considered model and its parameterizations. Yet there is high agreement that nearequatorial westerly wind biases causing an anomalous weak current of surface water, are a key factor for the simulated near-equatorial SST biases (Richter et al. 2012b). The consequential decrease in upwelling of cooler water causes positive temperature anomalies in the eastern basin. At this the positive Bjerknes feedback between SST gradient and near-surface winds enhances SST biases along the equator. Since equatorial westerly wind biases are even present in atmospheric general circulation models (AGCMs) forced by observed SSTs, atmospheric biases are suggested to play an important role in generating near-equatorial warm SST biases (Voldoire et al. 2014).
ESM historical simulation (1979-2005 period) is defined relative to AMIP-II reanalysis. Seasonal mean values are computed on the base of the monthly bias climatology used for the model setup of sensitivity experiment BIAS_mm

The poor representation of coastal upwelling is mainly caused by weaker than observed alongshore winds yielding reduced Ekman transport (Xu et al. 2014). A remote effect due to oceanic Kelvin waves may be relevant as well. Furthermore, due to the coarse horizontal resolution global models fail to represent small-scale orographic features as well as oceanic mesoscale eddies, both of them appear to be important mechanisms for coastal upwelling (Richter 2015).

Another important contributor to warm SST biases in the tropical Atlantic is the shortcoming of most general circulation models $(\mathrm{GCMs})$ to realistically simulate stratocumulus clouds. The well-documented underestimation of cloud cover in GCMs is element of a positive atmosphere-ocean feedback mechanism that favors to maintain and even intensify warm SST biases. Simulated reduced cloudiness leads to excessive downward shortwave radiation, warming the surface and consequently decreasing lower tropospheric stability and degrading favorable conditions of stratocumulus formation (Voldoire et al. 2014). To what extent the model resolution contributes to the simulated biases is still 
an open debate. A positive effect of increased resolution on horizontal winds can be found near coasts. It is linked to a better resolved land orography. Also, the relative importance of individual error sources and their coupling has not been fully addressed yet (Richter 2015).

While possible causes of tropical Atlantic SST biases have already been subject of numerous studies, there was very little effort spent on the examination of influences arising from these biases (Wahl et al. 2011; Murakami et al. 2014; Sasaki et al. 2014). That is why we want to address this issue in our study. How SST biases impact the simulation of climate appears to be an important question for the interpretation and reliability of model output. Ignoring consequences of such SST biases increases the uncertainty of projected global climate change. SST biases may drastically distort model results and by that possibly modify future climate projections, society relies on.

For instance, studies focusing on the role of SST anomalies in the tropical Atlantic sector (due to natural variability) document important correlations between Atlantic SSTs and regional rainfall (Fontaine and Janicot 1996; Yoon and Zeng 2010) as well as connections to climate in other basins (Kucharski et al. 2008). Consequently, SST biases being always present, artificial anomalies may cause substantial changes in climate simulations. Especially for the Amazon and Sahel region where future climate change is still very uncertain and inconsistently simulated in different GCMs (Borges et al. 2014; Saini et al. 2015), a quantification of changes depending on SST biases may be a useful information. Ashfaq et al. (2010) introduced a possible way of evaluating the influence of tropical SST biases on climate predictions by conducting a quantile-based bias correction. They found a substantial effect on precipitation distribution over many regions due to changes in atmospheric moisture content and circulation, driven by TA SST biases.

First studies discovered a positive feedback between warm SST errors in the south-eastern Atlantic, equatorial errors and precipitation (Toniazzo and Woolnough 2014). $\mathrm{Xu}$ et al. (2014) analyze multi-model ensembles from the Coupled Model Intercomparison Project Phase 5 and 3 archive (CMIP5 and CMIP3) and show that the SETA bias is responsible for a southward shift of the Atlantic ITCZ and a cooling of the tropical western Atlantic.

In this study, we want to approach the investigation of bias impacts in a more idealized way. Our analysis is based on atmosphere-only simulations using the AGCM ECHAM6. We force the model with a climatology of SST boundary conditions to neglect interannual variability and focus on annual mean state effects as well as implications on seasonal timescales. In different configurations, anomaly patterns limited to the tropical Atlantic region are added to the observed SST field that remains unchanged elsewhere.
With this new approach of addressing the mean-state SST bias problem by performing uncoupled atmospheric sensitivity experiments, we test the sensitivity of atmospheric climate simulations in ECHAM6 to TA SST biases. Aim of this study is also the comparison of the atmospheric response to TA SST biases with coupled model mean-state biases to derive the contribution of SST biases to the prevalence of other prominent biases in the MPI-ESM. Ignoring interannual variability in the boundary conditions does not only reduce complexity of our experiments but also allows for a general statement, if interannual variability is important for the contribution to coupled model meanstate biases at all. Disregarding atmosphere-ocean interactions, our experiments do not allow for a complete analysis of mechanisms driven by TA SST biases. However, due to the elimination of ocean feedbacks, the direct atmospheric response can be understood more easily and simulated changes are attributable to TA SST biases only because SSTs in all other basins are unchanged.

Besides examining the direct influence of tropical Atlantic SST biases on atmospheric circulation and precipitation patterns, the relevance of the temporal and spatial structure of the TA bias pattern will be elucidated. We will show that TA mean-state biases in the MPI-ESM have a strong seasonal cycle (Fig. 1) that must be considered for the analysis of the intra-annual atmospheric response. Furthermore, our sensitivity study demonstrates that cold biases in the western part of the tropical Atlantic are not minor important than positive SST biases in the SETA for the modulation of the basin-wide climate.

\section{Model and experimental design}

To investigate the impact of tropical Atlantic SST biases we perform a set of SST sensitivity experiments. Numerical model simulations for this study have been performed using the atmospheric general circulation model (AGCM) ECHAM6 (Stevens et al. 2013) (version 3). ECHAM6 is used as the atmospheric component in the fully comprehensive MPI Earth System Model (MPI-ESM) (Giorgetta et al. 2013). Here, we perform uncoupled AGCM simulations by prescribing global sea-surface temperatures and sea-ice concentrations (SICs). In our model configuration we use a Gaussian T63 grid providing $1.8^{\circ} \times 1.8^{\circ}$ horizontal resolution at the equator. 47 levels in the vertical resolve the atmosphere up to $0.01 \mathrm{hPa}(\sim 80 \mathrm{~km}$, high-top model). To reduce complexity and focus on the influence of tropical Atlantic SST biases on the climate mean state, we neglect interannual variability of the background state by forcing the model with climatological boundary conditions. Seasonal climatologies have been derived from historical AMIP-II boundary conditions (Taylor et al. 2000). 


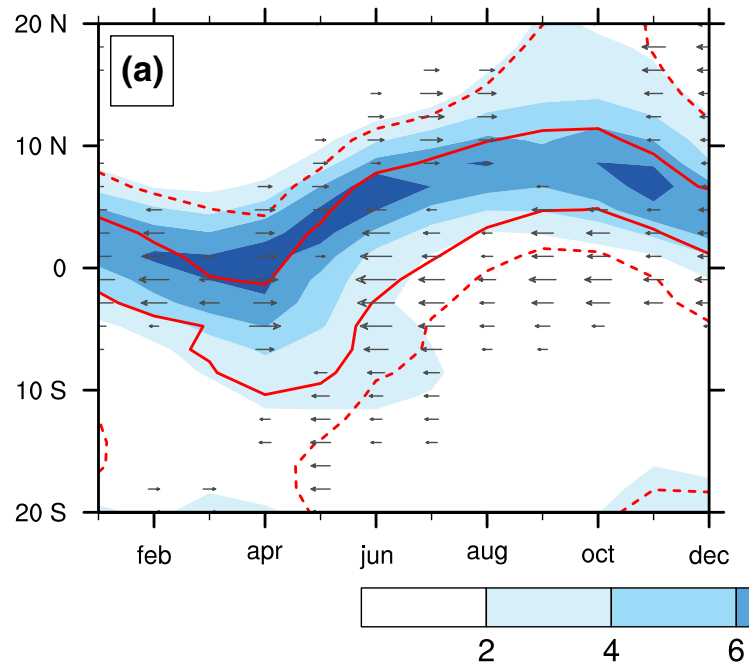

Fig. 2 Migration of the western (a) and eastern (b) Atlantic ITCZ. Shading shows observed monthly mean precipitation (GPCP) in $\mathrm{mm} /$ day, red contours the simulated precipitation in CTL. Dashed lines show the $2 \mathrm{~mm} /$ day isoline, solid lines the $8 \mathrm{~mm} /$ day one. Vectors

All experiments are integrated for 50 years to create a sufficient large ensemble to get statistical robust results.

Our control simulation (CTL) is forced by monthly mean SST and SIC boundary conditions, averaged over the historical period 1979-2008. Despite forcing the model with a climatology of observed SSTs, it simulates precipitation and wind biases (Siongco et al. 2014). Throughout the year the ITCZ in CTL is simulated broader than observed and slightly shifted to the south (Fig. 2). In the annual mean, CTL displaces the ITCZ maximum to the west while it is observed centered over the Atlantic. The precipitation bias is accompanied by a zonal wind bias predominating in the northeast of the Atlantic. These biases confirm common shortcomings among uncoupled AGCMs (Siongco et al. 2014; Voldoire et al. 2014).

Sensitivity experiments for this study are characterized by superimposing an SST bias pattern on the tropical Atlantic SST field in varying configurations. We define the tropical Atlantic as the maritime region from $30^{\circ} \mathrm{S}$ to $30^{\circ} \mathrm{N}$ with lateral boundaries of the North and South American continent in the west and Africa in the east (see also Fig. 1). Global SIC and SSTs outside the tropical Atlantic region remain unchanged compared to CTL. At the northern and southern boundaries of the tropical Atlantic region, SSTs have been smoothed towards the undisturbed SST field by computing weighted averages of each boundary grid point (weight 1.0) with its 8 surrounding points (weighted 0.5 above and aside, 0.3 in the corners), respectively. show the CTL zonal wind anomaly at $925 \mathrm{hPa}$ compared to NCEPII. All values are zonally averaged from $60^{\circ} \mathrm{W}$ to $25^{\circ} \mathrm{W}$ (a) and from $25^{\circ} \mathrm{W}$ to $10^{\circ} \mathrm{E}(\mathbf{b})$

The main bias pattern for the sensitivity experiments has been taken from a historical simulation of the MPIESM coupled model (version 1.1). The referred MPI-ESM simulation has been performed following the CMIP5 setup for post-1850 climate simulations incorporating closeto-observed forcing. To derive a climatological SST bias pattern for the tropical Atlantic, we have considered the years 1979-2005 only and compared simulated SSTs with AMIP-II reanalysis (Fiorino 2000), using monthly data of the respective period. As a first step, the simulated SST field has been corrected by removing the field-mean, monthly-mean bias in surface temperature within the global tropical belt $\left(30^{\circ} \mathrm{S}-30^{\circ} \mathrm{N}\right)$ for the considered period which varies between $-0.5 \mathrm{~K}$ (August) and $-1.3 \mathrm{~K}$ (March). This approach accounts for general MPI-ESM model biases in the tropics that are not limited to the Atlantic Ocean and therefore, are not the object of our study. Then, the SST bias pattern of the tropical Atlantic has been computed as the departure of corrected MPI-ESM SSTs from the observed state. Finally, a climatology has been calculated by averaging the resulting multi-year monthly anomalies over the whole period 1979-2005. Figure 1 shows the seasonal cycle of the resulting climatological SST bias pattern.

Based on the derived bias pattern, three different SST boundary conditions have been constructed. Table 1 describes main characteristics of the individual simulations. In experiment BIAS_mm the TA bias pattern is superimposed onto the SST field of CTL in its unchanged 
Table 1 Overview of conducted control simulation and SST sensitivity experiments under constant historical forcing

\begin{tabular}{ll}
\hline Experiment name & Tropical Atlantic SST bias pattern \\
\hline CTL & - \\
BIAS_mm & Full SST bias pattern \\
BIAS_mp & Positive component of the SST bias pattern \\
BIAS_am & Annual-mean SST bias pattern \\
\hline
\end{tabular}

All simulations are integrated for 50 years using ECHAM6 with climatological boundary conditions derived from the period 1979-2008

and complete shape. Consequently, BIAS_mm captures the climatological-mean seasonal variability in the TA as simulated by the MPI-ESM, including its biases. For a better understanding of the simulated response, two additional experiments are performed. In BIAS_mp, solely the positive part of the SST bias pattern, mainly located in the SETA, is considered. The experiment helps to eliminate the atmospheric response to the part, that can be attributed to positive biases in the TA only. It conforms to a differential warming of the Southern Atlantic. Experiment BIAS_ am is characterized by superposing the annual-mean bias pattern onto the control field for each month, neglecting the seasonal evolution of the coupled model biases. Both BIAS_mp and BIAS_am serve as potential simplification of the spatial and temporal structure of the primitive bias pattern.

Additionally, since one fundamental scope of application of GCMs is the projection of future climate, we examine the atmospheric response to tropical Atlantic SST biases in a simplified global warming scenario (Table 2). Idealizing global warming by a homogeneous increase of global SSTs by $2 \mathrm{~K}$ and suggesting that the MPI-ESM SST bias pattern remains unchanged under warmer conditions, we rerun CTL and the sensitivity experiment BIAS_mm with this changed background state.

Table 2 Experimental setup under idealized global warming (Table 1)

\begin{tabular}{ll}
\hline Experiment name & Tropical Atlantic SST \\
\hline $\mathrm{CTL}+2 \mathrm{~K}$ & AMIP-II climatology increased by 2 K \\
BIAS $+2 \mathrm{~K}$ & $\begin{array}{l}\text { Same as CTL+2K, with full SST bias pattern } \\
\text { superposed }\end{array}$ \\
\hline
\end{tabular}

Global warming is studied by globally increasing SST boundary conditions by $2 \mathrm{~K}$

The superimposed bias pattern remains unchanged compared to BIAS_mm

\section{Analysis methods}

Impacts of TA SST biases on the atmospheric circulation and precipitation distribution are examined by focusing on differences of monthly mean values between SST sensitivity experiments and the AGCM control simulation (BIAS_ $x x-$ CTL). Using a two-tailed Student's $t$ test we focus on simulated changes that are statistical significant at the $95 \%$ confidence level.

Assessing model performance skill and relative importance of biases in both of the coupled model and uncoupled sensitivity experiments we compare our results to observations and reanalysis data. As reference for global precipitation we use the Global Precipitation Climatology Project (GPCP) Version-2 monthly precipitation analysis (Adler et al. 2003). For global surface temperature and horizontal winds we use the NCEP-DOE AMIP-II reanalysis (R-2), since it is consistent with AMIP-II boundary conditions of SST and SIC that are used in our sensitivity experiments (Kanamitsu et al. 2002). All data has been bilinearly interpolated to T63 horizontal resolution to match the ECHAM6 resolution used in this study.

To quantify simulated changes of a parameter $X$ compared to its reference state $O$ (e.g. CTL, observations, reanalysis) and relate it to mean state biases in the coupled model we define its bias index $B I_{X}$ as:

$B I_{X}=\frac{\langle\bar{X}\rangle-\langle\bar{O}\rangle}{\langle\bar{O}\rangle}$.

Overbars indicate the time mean, angle brackets the area average over a certain domain.

\subsection{Changes in the moisture budget}

For a detailed analysis of the SST bias impact on the hydrological cycle we divide its response into two components: a dynamical component due to mean horizontal circulation changes $\delta \overline{\mathbf{u}}$, and a thermodynamic one, dependent on changes in mean specific humidity $\delta \bar{q}$, only. According to the moisture budget equation (Eq. 2) the variation of precipitable water $W$ in the atmosphere is determined by the sum of precipitation $P$, evaporation $E$, and convergence of vertically integrated moisture flux $q \mathbf{u}$ :

$\frac{\partial W}{\partial t}=P-E-\nabla \cdot \frac{1}{g} \int_{0}^{p_{s}} q \mathbf{u} d p$.

On long-term averages the local derivative of $W$ is negligible small. Then, the net flux of water substance at the surface $(P-E)$ is balanced by the convergence of vertical integrated moisture flux $q \mathbf{u}$, only (Trenberth and Guillemot 1995). Linearization of this equation and taking the 


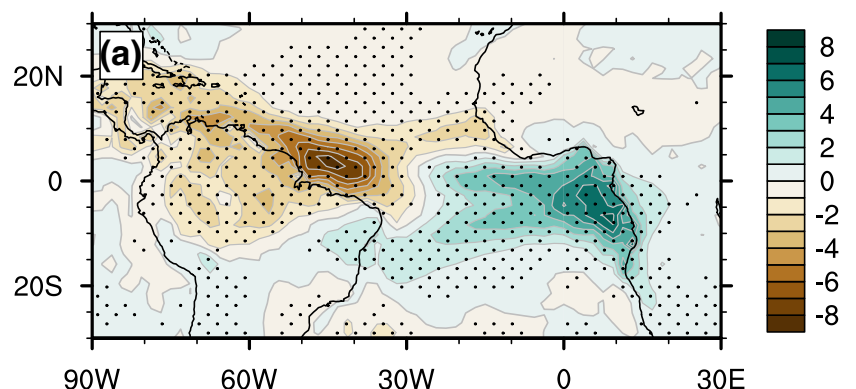

Fig. 3 In the annual mean BIAS_mm shows a dry bias along the Brazilian coast and a wet bias over the Gulf of Guinea compared to CTL. a Precipitation difference in $\mathrm{mm} /$ day. b Difference in surface

divergence operator inside the vertical integration leads to the following formulation of the equation:

$$
\begin{aligned}
P-E= & -\frac{1}{g} \int_{0}^{p_{s}} \overline{\mathbf{u}} \cdot \nabla \bar{q} d p-\frac{1}{g} \int_{0}^{p_{s}} \bar{q} \nabla \cdot \overline{\mathbf{u}} d p \\
& -\frac{1}{g} \int_{0}^{p_{s}} \nabla \cdot\left(\overline{\mathbf{u}^{\prime} q^{\prime}}\right) d p-\frac{q_{s}}{g} \overline{\mathbf{u}}_{\mathbf{s}} \nabla p_{s} .
\end{aligned}
$$

The subscript $s$ in the fourth term on the right hand-side indicates surface quantities, overbars monthly-mean values, and primes departures from the monthly mean. The term including surface quantities results from the generic relation

$\nabla \cdot \int_{0}^{p_{s}} q \mathbf{u} d p=\int_{0}^{p_{s}} \nabla \cdot(q \mathbf{u}) d p+q_{s} \mathbf{u}_{\mathbf{s}} \cdot \nabla p_{s}$.

and will be neglected because it is mainly dependent on orographic features and small compared to the other terms (Pomposi et al. 2014). Considering differences in the net flux of surface water substance $\delta(P-E)$ (e.g. between sensitivity simulations and control run) we can break down Eq. 4 into forcing driven by mean circulation changes (dynamic component), and forcing due to variations in mean specific humidity (thermodynamic component):

$$
\begin{aligned}
\delta(P-E)= & \overbrace{-\frac{1}{g} \int_{0}^{p_{s}} \delta \overline{\mathbf{u}} \cdot \nabla \bar{q} d p-\frac{1}{g} \int_{0}^{p_{s}} \bar{q} \nabla \cdot \delta \overline{\mathbf{u}} d p}^{\text {advective and divergent dynamic component }} \\
& \overbrace{-\frac{1}{g} \int_{0}^{p_{s}} \overline{\mathbf{u}} \cdot \nabla \delta \bar{q} d p-\frac{1}{g} \int_{0}^{p_{s}} \delta \bar{q} \nabla \cdot \overline{\mathbf{u}} d p}^{\text {submonthly transient eddies }} \\
& \overbrace{-\frac{1}{g} \int_{0}^{p_{s}} \nabla \cdot \delta\left(\overline{\mathbf{u}}^{\prime} q^{\prime}\right) d p}
\end{aligned}
$$

Vertical integration of model quantities is approximated by a summation over all model levels $k$ :

$$
\int_{0}^{p_{s}} \mathbf{u} q d p \approx \sum_{k=1}^{47} \mathbf{u}_{k} q_{k} \Delta p_{k} .
$$

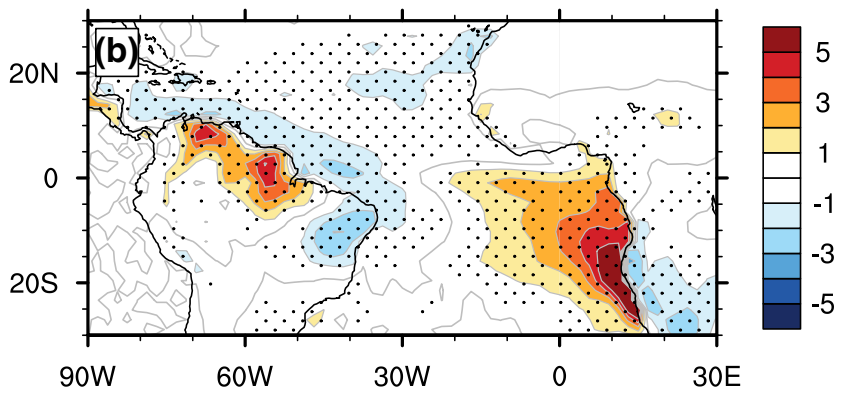

temperature in K. Dotted areas indicate differences statistically significant at the $95 \%$ confidence level

Since we base our analysis on monthly-mean quantities, only, in the following study we do not investigate the role of transient eddies in changing the net surface water budget.

Generally, two main theories about changes in tropical rainfall exist (Huang et al. 2013): the first one claims that tropical rainfall changes follow a "wet-get-wetter" pattern, stating that rainfall increases in already wet regions. The other theory links the increase in rainfall to those regions, where the surface warming exceeds the area-mean tropical warming ("warmerget-wetter"). As Huang et al. (2013) show in their study, the "wet-get-wetter" mechanism corresponds to the thermodynamic component (Eq. 5, terms $3+4$ on the right hand side) while the "warmer-get-wetter" effect is directly coupled to the dynamic component (Eq. 5, terms $1+2$ on the right hand side).

\section{Results}

\subsection{Annual mean Atlantic ITCZ response}

As a result of TA SST biases, annual mean precipitation changes across the tropical Atlantic are mainly characterized by an eastward shift of the rainfall maximum, and expansion and southward movement of the zonal-mean ITCZ. Tropical precipitation mainly follows maximum SSTs in our model. Bias-induced near-equatorial rainfall changes are driven by circulation changes obeying the "warmer-get-wetter" theory while changes in the subtropical eastern Atlantic are thermodynamically forced, in accordance with the "wet-get-wetter" mechanism (Sect. 3.1).

The TA SST bias pattern leads to a substantial decrease in precipitation over the northwestern tropical Atlantic (NWTA), and an increase across the SETA (Fig. 3). The drying is most intense along the northwestern coast of South America, located above cold SST anomalies. However, a comparison shows that precipitation changes are not one-to-one associated with the SST anomalies. 

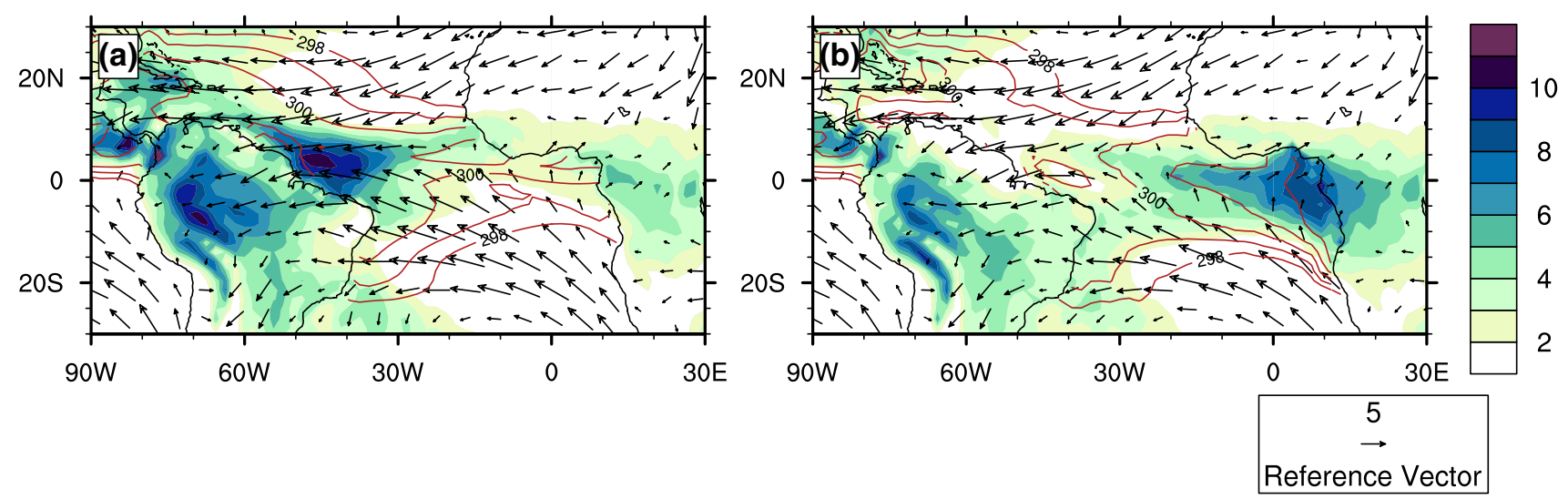

Fig. 4 Under the influence of TA SST biases the annual mean precipitation maximum shifts from the west (CTL) to the east (BIAS $\mathrm{mm}$ ) of the basin. The precipitation displacement comes along with

an intense zonal wind bias. Precipitation is plotted in $\mathrm{mm} / \mathrm{day}$, vectors show the horizontal wind $(\mathrm{m} / \mathrm{s})$ in $925 \mathrm{hPa}$, red contours the SST in K. a CTL simulation, b BIAS_mm sensitivity experiment
Fig. 5 Under the impact of TA SST biases (BIAS_mm) an anomalous overturning circulation builds up along the equator where we would expect the Atlantic Walker Circulation Cell. Colors show annual mean differences in vertical velocity, contour lines indicate differences in the zonal wind component. Values have been meridionally averaged from $2^{\circ} \mathrm{S}$ to $2^{\circ} \mathrm{N}$. Units are $\mathrm{m} / \mathrm{s}$

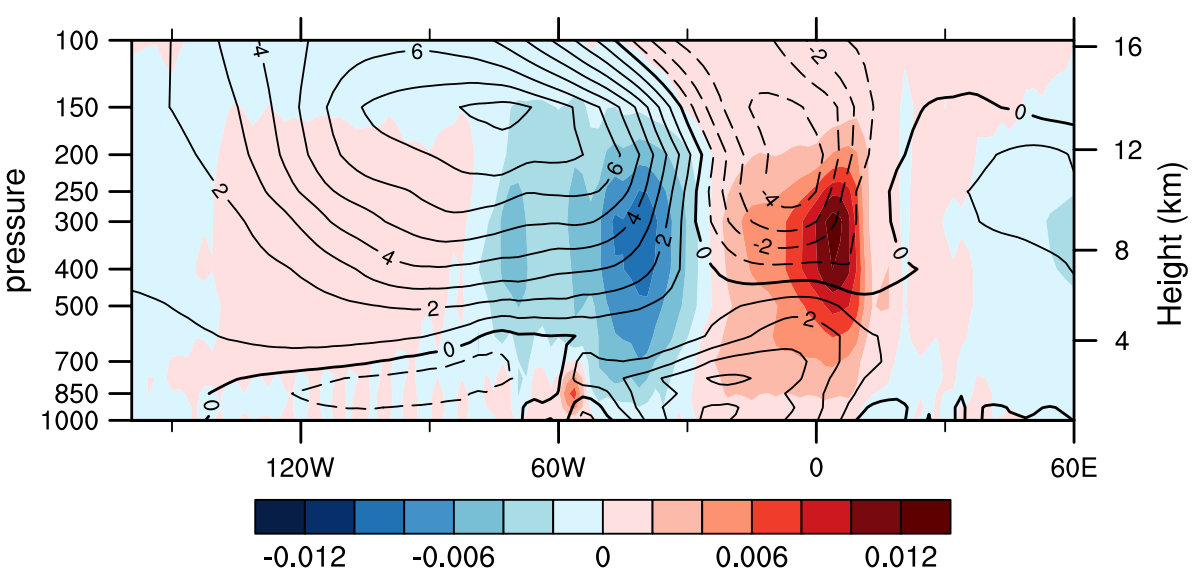

Increasing rainfall is located over the Gulf of Guinea and peaks at the coast of Gabon, while the SST bias pattern has its positive peak anomaly further to the south at the Namibian coast.

The mean response in tropical Atlantic precipitation depends on changes in absolute SSTs induced by the bias pattern (Fig. 4). Following high SSTs, the precipitation maximum zonally shifts eastwards. When forcing ECHAM6 with observed SSTs in the tropical Atlantic region (CTL), maximum rainfall is simulated in the west of the basin. This conforms with results from Siongco et al. (2014) who analyzed the position of the Atlantic ITCZ in AGCMs compared to observations. In their study they show that in AMIP-type simulations the model ECHAM6 misplaces oceanic precipitation clusters westwards the observed location centered over the Atlantic. Introducing the tropical Atlantic SST bias pattern (BIAS_mm) generates highest SSTs in the Gulf of Guinea and by that causes the Atlantic precipitation maximum to shift from its western location to the eastern Atlantic. The west-to-east shift of maximum precipitation is accompanied by a weakening of near-equatorial easterly trades (Fig. 4) driven by the reversal of the zonal SST gradient. Over the central Atlantic the zonal wind component is reduced to more than half of its value in CTL. Over the Gulf of Guinea zonal winds change sign yielding a westerly flow. These changes in near-equatorial low-level wind are directly coupled to anomalous rising motion at $0^{\circ} \mathrm{E}$ and sinking motion around $45^{\circ} \mathrm{W}$ (Fig. 5). Vertical and horizontal circulation changes result in a substantial weakening of the Atlantic Walker circulation cell which is known to be thermally driven (James 1994).

Besides the zonal displacement of maximum rainfall, under the influence of SST biases the annual mean ITCZ broadens towards the south (Fig. 4). Imposed SST biases cause a meridional widening of the rain belt of about $6^{\circ}$. The zonal-mean Atlantic rainfall maximum is meridionally shifted to the south. This result demonstrates that SST biases in the TA worsen the already too far southward 
Fig. 6 Due to TA SST biases (BIAS_mm) the branch of rising motion of the annual mean Hadley Cell moves southward and broadens. Colors show the difference in zonal mean vertical wind component averaged from $70^{\circ} \mathrm{W}$ to $10^{\circ} \mathrm{E}$. Contour lines indicate vertical velocities of the CTL run. Units are $\mathrm{mm} / \mathrm{s}$

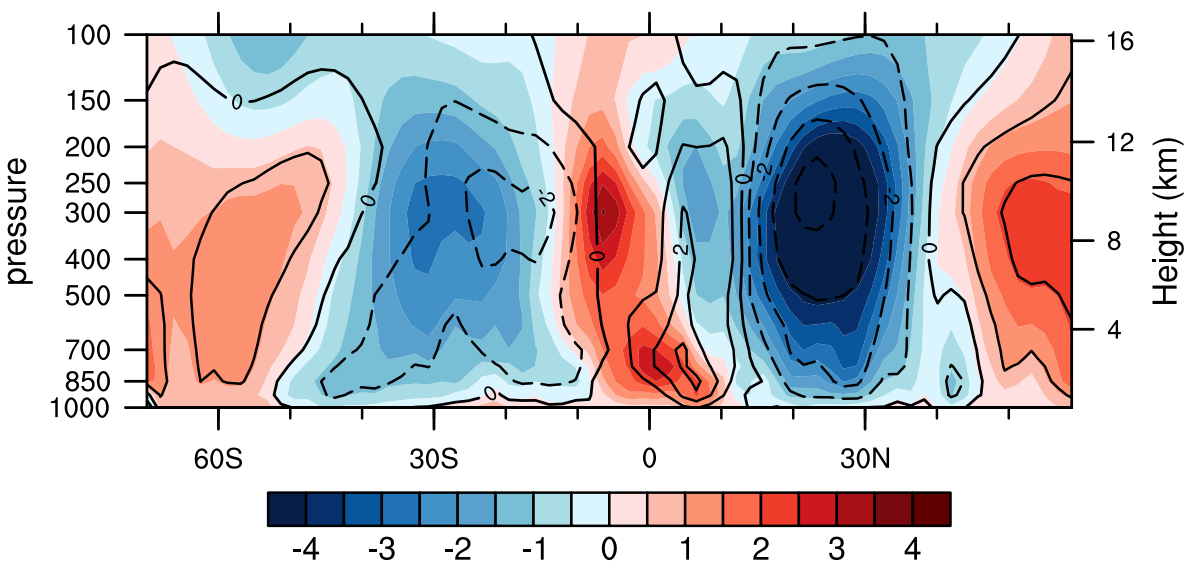

Table 3 MPI-ESM SST biases in the tropical Atlantic cause a reversal of the annual mean large-scale north-south Atlantic SST gradient

\begin{tabular}{lllll}
\hline Experiment & CTL & BIAS_mm & BIAS_mp & BIAS_am \\
\hline NS SST gradient $[\mathrm{K}]$ & 1.60 & -0.77 & -0.16 & -0.77 \\
\hline
\end{tabular}

The NS gradient is calculated as difference between the tropical North Atlantic SST, averaged over the domain of $60^{\circ} \mathrm{W}-15^{\circ} \mathrm{W}$ and $5^{\circ} \mathrm{N}-20^{\circ} \mathrm{N}$, and the tropical South Atlantic SST, averaged over the domain of $30^{\circ} \mathrm{W}-10^{\circ} \mathrm{E}$ and $0^{\circ} \mathrm{N}-20^{\circ} \mathrm{S}$

simulated ITCZ in ECHAM6 (see Fig. 2). The change in meridional ITCZ structure conforms with a modification of the annual-mean Hadley circulation over the Atlantic basin (Fig. 6). While in CTL the branch of ascending motion is located north of the equator, BIAS_mm simulates it slightly south of the equator. Furthermore, the region of rising motion broadens in agreement with the meridional broadening of the ITCZ. The meridional modulation of the Hadley Cell branch of rising motion is associated with the large-scale interhemispheric north-south SST gradient (Table 3).

Due to the SST bias pattern we differentially warm the southern tropical Atlantic. This warming forces a southward movement of the ITCZ towards the warmed hemisphere (Schneider et al. 2014). In our experiment the bias pattern generates not only a weakening of the SST gradient being positive in CTL, but a reversal. Due to the intense warming south of the equator and the cooling north of the equator in BIAS_mm at the same time, the south tropical Atlantic is warmer than the north tropical Atlantic. For this reason the branch of rising motion of the Hadley Cell is displaced to the southern hemisphere.

All in all, our experiments show a close connection between SST biases in the TA and the forcing of precipitation and wind changes in ECHAM6. The response of precipitation and circulation in BIAS_mm bears high resemblance with coupled model mean state biases (Richter et al. 2012a), as for example the weaker than observed equatorial easterlies across the Atlantic. We have also shown that precipitation changes in BIAS_mm are linked to anomalies in the tropical vertical overturning circulations.

A break down of the moisture budget equation allows for a more detailed analysis of simulated changes in the global hydrological cycle. In agreement with the southward shift of the Atlantic ITCZ the annual mean $P-E$ difference as indicator for wet $(P>E)$ and dry regions
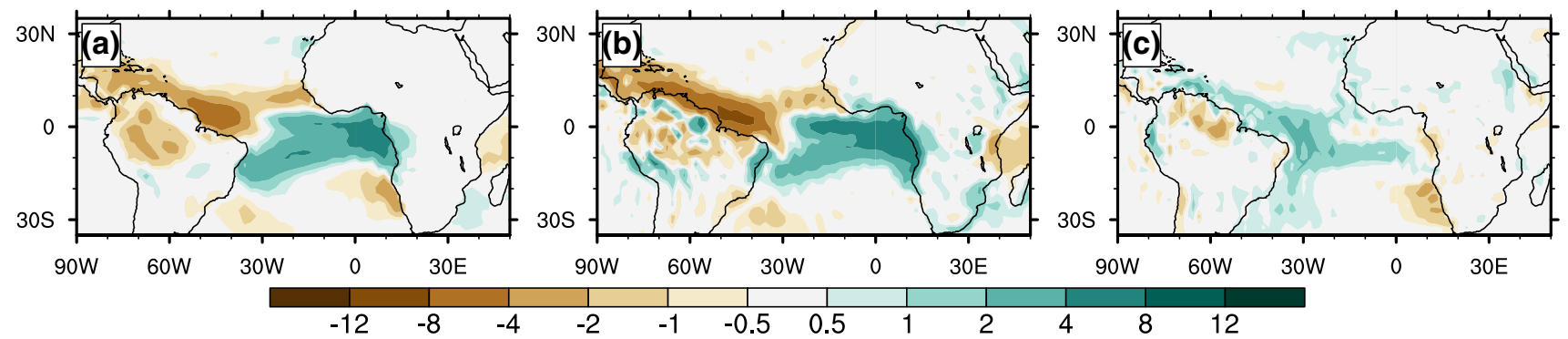

Fig. 7 Near-equatorial changes in the moisture budget at the surface $(P-E)$ due to TA SST biases are mainly caused by anomalous divergence and convergence (divergent dynamic component). In the eastern basin south of $15^{\circ} \mathrm{S}$ arising difference are forced by the advective thermodynamic component. Colors show annual mean differences in $\mathrm{mm} /$ day. a $\delta(P-E)$, b divergent dynamic component $-\frac{1}{g} \int_{0}^{p s} \bar{q} \nabla \cdot \delta \overline{\mathbf{u}} d p$, c advective thermodynamic component of the moisture budget equation $-\frac{1}{g} \int_{0}^{p s} \overline{\mathbf{u}} \cdot \nabla \delta \bar{q} d p$ 
$(P<E)$ displays a migration of wet regions towards the south (Fig. 7a). In the deep tropics $\left(15^{\circ} \mathrm{S}-15^{\circ} \mathrm{N}\right)$ this hydrology change is determined by the third (divergent dynamic) term on the right hand side of the moisture budget equation (Eq. 5, Fig. 7b):

$\delta(P-E) \approx-\frac{1}{g} \int_{0}^{p s} \bar{q} \nabla \cdot \delta \overline{\mathbf{u}} d p$.

This reveals the dominant role of mean horizontal circulation changes $\delta \overline{\mathbf{u}}$ in changing the distribution of precipitation across the Atlantic compared to changes in specific humidity. This in turn satisfies the "warmer-get-wetter" theory for precipitation changes in the tropics (Huang et al. 2013). Furthermore, Eq. 7 emphasized that the relevant contribution of circulation changes can be reduced to the divergent component. This means that arising anomalies in horizontal divergence and convergence that couple to anomalous vertical atmospheric motion control the pattern of $\delta(P-E)$.

In higher latitudes (outside $15^{\circ} \mathrm{S}-15^{\circ} \mathrm{N}$ ) in the eastern basin outside the catchment area of the ITCZ changes in the net surface water budget $\delta(P-E)$ are dominated by evaporative changes. These changes are thermodynamically driven, thus driven by changes in specific humidity $\delta \bar{q}$ and obey the "wet-get-wetter" or rather "dry-get-drier" theory (Held and Soden 2006). Using the moisture budget equation allows for a reduction of the forcing term to the advective thermodynamic component (Fig. 7c):

$\delta(P-E) \approx-\frac{1}{g} \int_{0}^{p s} \overline{\mathbf{u}} \cdot \nabla \delta \bar{q} d p$.

This shows that in the considered subtropical region the response in $\delta(P-E)$ is controlled by anomalous moisture advection due to a changed gradient in specific humidity. Specific humidity is changing because of increased evaporation over the SETA due to the positive SST biases located there.

Experiments BIAS_am and BIAS_mp reproduce main characteristics in annual-mean precipitation change with similar patterns but varying amplitudes compared to the response BIAS_mm. Superimposing the tropical Atlantic annual-mean bias (BIAS_am) instead of the monthly bias climatology (BIAS_mm) leads to a slight intensification of the observed response in BIAS_mm. In case of reducing the SST bias pattern to its positive component (BIAS_mp), the annual mean precipitation response is less pronounced and mainly present in a precipitation increase along the Guinea Coast while the drying over Brazil is very weak. The intercomparison of all sensitivity experiments shows high agreement between the annual mean precipitation change and the variation of large-scale interhemispheric SST gradients in the tropical Atlantic (Table 3). The southward shift of the Atlantic rain belt is most pronounced in BIAS_mm and BIAS_am, as the North-South (NS) SST gradient shows the largest weakening. In other words the bias pattern considering both positive and negative anomalies imposes a larger change of the interhemispheric energy balance by warming the South TA and cooling the North TA, than solely the component of warm SST biases. This significantly effects the ITCZ position as it controls the cross-equatorial energy flux (Schneider et al. 2014). Considering both positive and negative anomalies in the bias pattern in BIAS_mm and BIAS_am also contributes to a larger anomalous zonal SST gradient than in BIAS_mp. This yields a less pronounced zonal wind bias in BIAS_mp and a less intense weakening of the Walker circulation. Forcing the model with the annual mean bias pattern in each month (BIAS_am) causes an overestimation of the zonal SST gradient anomaly on intraseasonal time-scales leading to an increased annual-mean zonal wind change evidencing a reversal of near-equatorial zonal winds in the eastern basin.

\subsection{Influence on the seasonal cycle of the Atlantic ITCZ}

The seasonal oceanic ITCZ response in the tropical Atlantic sector differs substantially between the individual SST sensitivity experiments. This is in contrast to the annual mean response which appears to be qualitatively similar in BIAS_mm, BIAS_mp, and BIAS_am (Sect. 4.1). Results show a high dependence of the ITCZ latitudinal position and the seasonal-mean meridional SST gradient between the tropical North and South Atlantic. ITCZ shifts are most pronounced in DJF in the western basin and in JJAS in the eastern basin. Zonal wind anomalies drive the strength of western Atlantic drying and eastern Atlantic wetting and are controlled by the monthly near-equatorial zonal SST gradient. Because the general structure of the Atlantic ITCZ is not zonally symmetric we will analyze it by looking at its eastern and western part separately.

Under the influence of SST biases in the tropical Atlantic (BIAS_mm) western Atlantic rainfall decreases to half of the simulated precipitation in CTL from April-October due to anomalous sinking motion forced by the cold SST biases along the South American coast (Fig. 8). As it has already been detected on annual mean time-scales, the seasonal rainfall response across the Atlantic is dynamically driven, too. Tropical Atlantic mean overturning circulations exhibit high sensitivity to the underlaying SST pattern that is substantially modified by the inclusion of SST biases. The strong linkage between SSTs and mean circulation causes a displacement of zones of maximum moisture convergence that provokes precipitation changes.

Because of the warm SST biases in the south TA, in DJF the western ITCZ shifts southward from its seasonal mean position of $5^{\circ} \mathrm{S}-10^{\circ} \mathrm{N}$ to $20^{\circ} \mathrm{S}-5^{\circ} \mathrm{S}$ (Fig. 8), following warm SSTs. This simulated southward shift of the ITCZ 

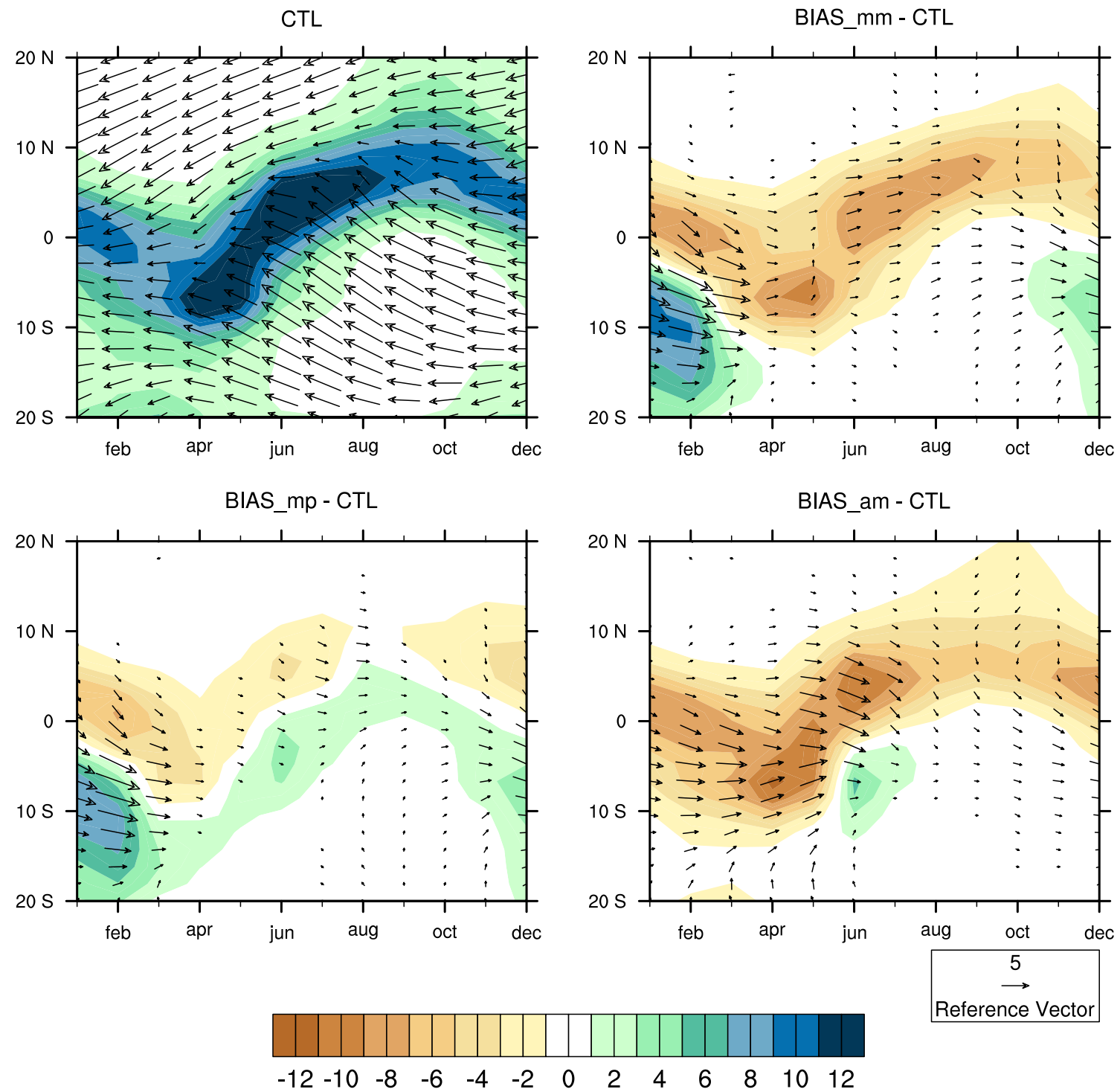

Fig. 8 Annual migration of the western part of Atlantic ITCZ in CTL and the individual sensitivity experiments. Colors show monthly mean precipitation in $\mathrm{mm} /$ day, vectors $925 \mathrm{hPa}$ horizontal winds in $\mathrm{m} / \mathrm{s}$. All values are averaged from $60^{\circ} \mathrm{W}$ to $25^{\circ} \mathrm{W}$

in DJF depends mainly on the positive SST biases in the SETA generating a substantial interhemispheric SST gradient anomaly. This is confirmed by sensitivity experiment BIAS_mp which equivalently simulates the shift of the rain belt (Fig. 1). In turn BIAS_am does not capture the western ITCZ shift in DJF because it does not cover the seasonal spread of positive biases across the southern Atlantic that prevails in BIAS_mm and BIAS_mp and causes the substantial southern tropical Atlantic warming.

From the analysis in Sect. 4.1 we know that the substantial drying in BIAS_mm across the western Atlantic is due to a zonal shift of the rainfall maximum to the east, driven by a slow-down of the Walker circulation, that in turn is forced by the anomalous equatorial SST gradient. Because disregarding negative biases in the pattern does not capture the strong zonal SST gradient anomaly, BIAS_mp cannot reproduce the drying taking place from April to October in the western basin. In agreement to this interpretation experiment BIAS_am that includes equatorial cold biases in the west and warm biases in the east similarly simulates the drying in the western Atlantic during boreal summer as seen in experiment BIAS_mm (Fig. 8).

In the eastern tropical Atlantic the ITCZ is broadened towards the south accompanied by strong anomalous westerlies throughout the year when considering the full SST bias pattern (Fig. 9). Arising near-equatorial westerly wind anomalies are due to the anomalous zonal SST gradient that generates a pressure gradient anomaly. Farther away from the equator the westerly wind anomaly is caused by the decrease of easterly momentum advection through 
CTL
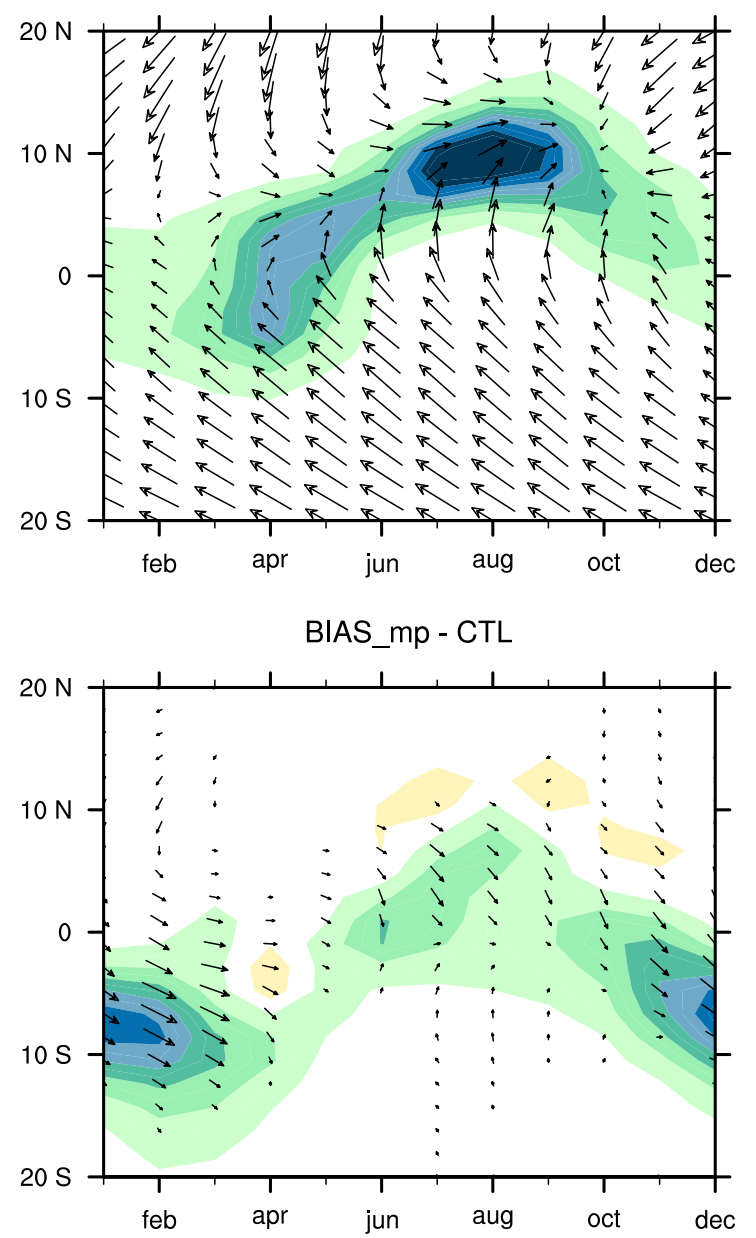

BIAS_mm - CTL

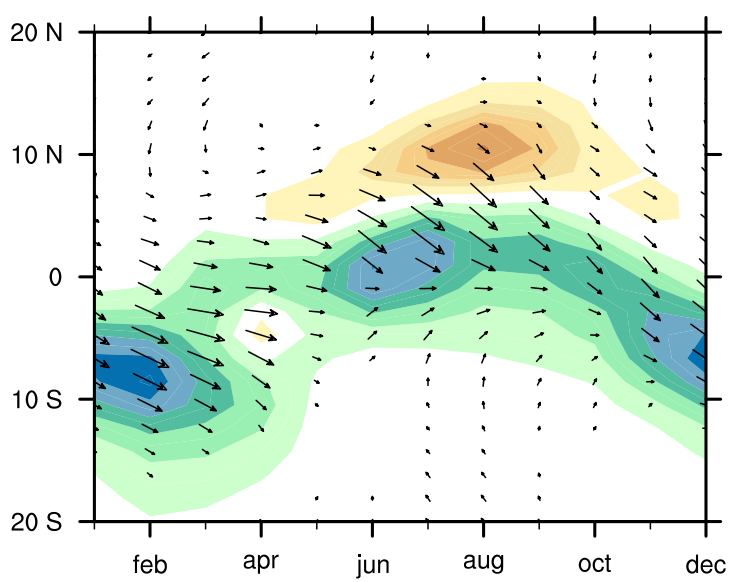

BIAS am - CTL

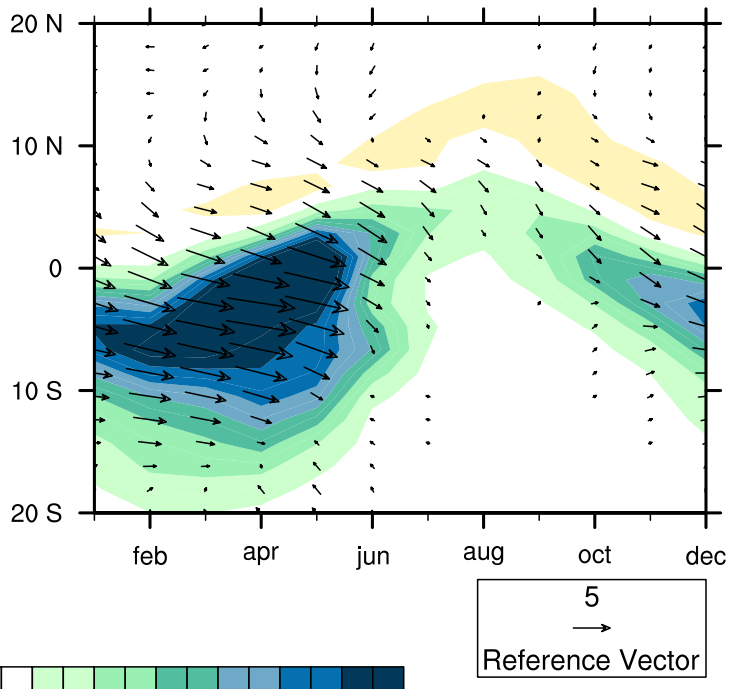

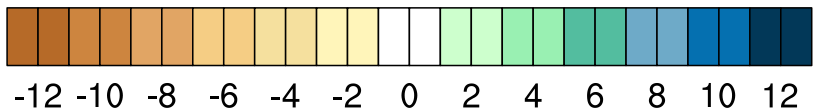

Fig. 9 Annual migration of the eastern part of Atlantic ITCZ in CTL and the individual sensitivity experiments. Colors show monthly mean precipitation in $\mathrm{mm} /$ day, vectors $925 \mathrm{hPa}$ horizontal winds in $\mathrm{m} / \mathrm{s}$. All values are averaged from $25^{\circ} \mathrm{W}$ to $10^{\circ} \mathrm{E}$

meridional winds within the rain belt. The widening of the rain belt is most intense during winter and spring, when the ITCZ reaches almost the double of its width in CTL. During June-September, in addition to the zonal wind bias there is an anomalous meridional wind component preventing the northern flank to expand northward, causing a dry bias north of $5^{\circ} \mathrm{N}$. BIAS_mp covers the general structure of the seasonal cycle of the eastern Atlantic ITCZ response very well. This simplified sensitivity experiment however fails to produce the shift of maximum rainfall during JuneSeptember, emphasizing the contribution of cold biases near the West African Coast in the tropical North Atlantic (Fig. 1). In experiment BIAS_am during winter and spring the precipitation increase and westerly wind bias is more intense than in BIAS_mm due to the the larger zonal SST gradient. During JJAS the annual mean SST bias shows a less intense equatorial SST gradient anomaly than monthly varying pattern in BIAS_mm. As a consequence, simulated anomalies of both precipitation and zonal wind turn out to be weaker.

\subsection{Seasonal rainfall changes over adjacent continents}

Our sensitivity experiments reveal that both precipitation biases over Brazil and West Africa prevailing in the coupled MPI-ESM are largely attributable to SST biases in the tropical Atlantic. In this section we will focus on seasonal rainfall changes over West Africa and Brazil during 


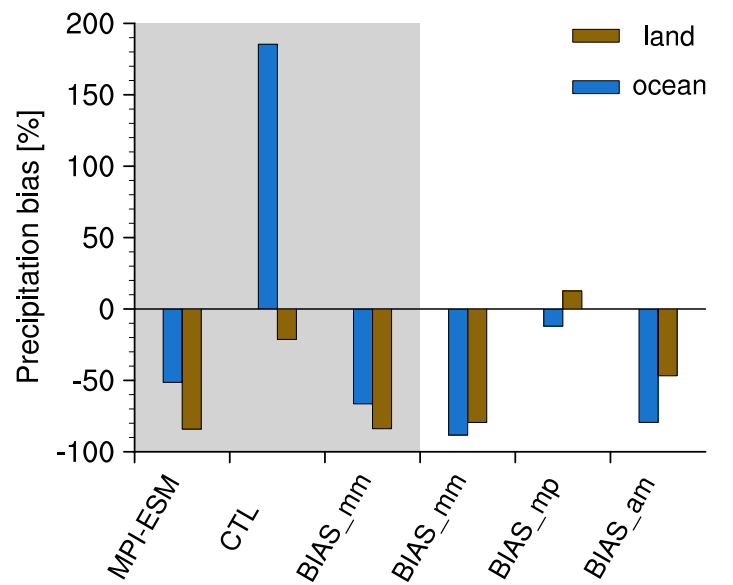

Fig. 10 JAS precipitation biases over Amazon-Brazil in BIAS_mm are comparable to the coupled model biases in this region. In the grey area precipitation bias indices are shown relatively to observations. Bars in the white area show the bias indices relatively to CTL. Blue bars show the bias index for grid points over sea, brown bars for those over land. JAS mean precipitation has been averaged over the domain of $60^{\circ} \mathrm{W}-40^{\circ} \mathrm{W}$ and $5^{\circ} \mathrm{S}-10^{\circ} \mathrm{N}$ where precipitation changes in the sensitivity experiments are statistically significant

July-September, which is known to be the season most sensitive to rainfall changes forced by tropical Atlantic SSTs (Fontaine and Janicot 1996; Yoon and Zeng 2010). For both regions we consider regional mean precipitation biases to quantify the impact of TA SST biases following our definition of the bias index (Eq. 1).

Comparing MPI-ESM precipitation over Brazil with observations shows that the coupled model produces a large dry bias both over land and over sea (Fig. 10). This dry bias over tropical South America is prevalent in many AOGCMs (Yin et al. 2013; Ryu and Hayhoe 2014). It has been established that dry events over Brazil and the Amazon in general are driven by SST anomalies in the Pacific and Atlantic oceans through their influence on moisture patterns and atmospheric circulation (Yoon and Zeng 2010). Over land, surface feedbacks and soil moisture play a role, too (Wang and $\mathrm{Fu} 2002$ ).

Through our experimental setup we can show that a large part of the MPI-ESM dry bias in JAS over Brazil is attributable to TA SST biases. Superposing the complete bias pattern onto the observed state reproduces large parts of this precipitation anomaly over tropical South America (Fig. 10). In agreement with Hagemann et al. (2013) TA SST biases amplify the dry bias over land, already present in CTL, when forcing the model with observed SSTs. Analyzing experiments BIAS_mp and BIAS_am it can be concluded that cold biases in the northwestern TA play a major role in causing this rainfall anomaly while prescribing only positive biases does have almost no effect on Brazilian rainfall. For this reason BIAS_mp does not capture the drying. Over

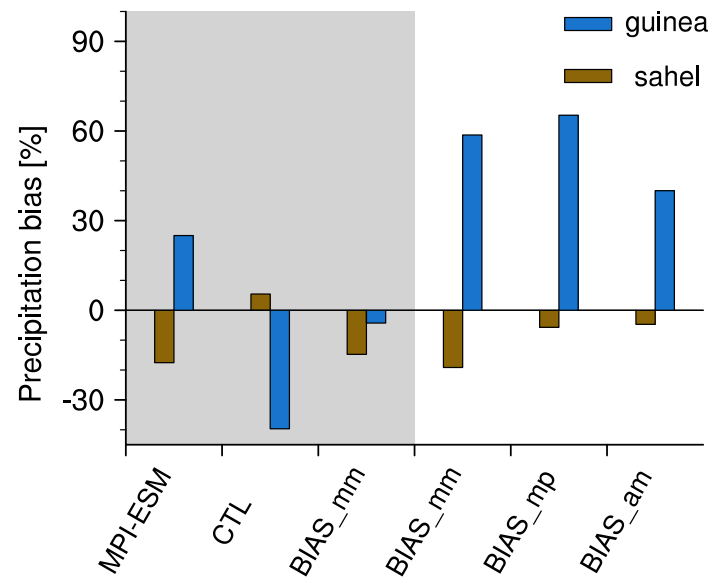

Fig. 11 Under the influence of TA SST biases in BIAS_mm ECHAM6 produces a substantial dry bias over the Sahel region of comparable magnitude as the MPI-ESM. The positive precipitation bias of the MPI-ESM over the Guinea Coast is not fully captured. In the grey area precipitation bias indices are shown relatively to observations. Bars in the white area show the bias indices relatively to CTL. Blue bars indicate the precipitation bias for the Guinea Coast (area average of $15^{\circ} \mathrm{W}-10^{\circ} \mathrm{E}$ and $4^{\circ} \mathrm{N}-10^{\circ} \mathrm{N}$ ), brown bars that one for the Sahel (area average of $18^{\circ} \mathrm{W}-20^{\circ} \mathrm{E}, 10^{\circ} \mathrm{N}-20^{\circ} \mathrm{N}$

land, the decrease in precipitation depends not only on the off-coastal cold bias but also on the large-scale equatorial SST gradient modified by the bias pattern, forcing anomalous westerlies over tropical South America (Fig. 8). That is why the precipitation anomaly turns out to be weaker in BIAS_am than in BIAS_mm (Fig. 10), because in BIAS_ am during JAS the anomalous zonal gradient is weaker.

In the climatological mean summer (JAS) the MPI-ESM simulates too much rainfall along the Coast of Guinea and too weak rainfall over the Sahel region (Fig. 11). This anomalous dipole-like precipitation pattern is reproduced by our sensitivity experiments. To quantify precipitation changes during JAS over West Africa, we refer to the commonly used Guinea Coast and Sahel precipitation index. In comparison with the simulated precipitation in CTL all sensitivity experiments show a decrease in Sahel rainfall and an increase in rainfall across the Coast of Guinea (Fig. 11). Thus all experiments are capable to reproduce the general rainfall bias signal of the coupled model. The precipitation change is driven by the decrease in land-sea temperature contrast set up by positive SST biases in the SETA. The decrease in temperature gradient results in a reduction of the pressure gradient between ocean and land which in turn weakens the onshore winds transporting moisture from the SETA to West Africa. This result fits to the change in ITCZ position (Fig. 9): in boreal summer all sensitivity experiments display a shift of the rain belt towards the south accompanied by a widening of the rainband towards the south. The correlation between the dipole-like rainfall anomaly across West Africa and a shift of the Atlantic 
ITCZ conforms to other AOGCM studies (Saini et al. 2015; Druyan 2011).

\section{Discussion and conclusions}

As our study shows, the awareness of the influence of tropical Atlantic SST biases is important for a reliable interpretation of global climate simulations because these biases cause substantial changes in simulated regional precipitation and atmospheric circulation. The climate in the tropics is mainly determined by properties of regional rainfall. Tropical rainfall in turn is controlled by the ITCZ position and structure which is directly coupled to atmospheric overturning circulation systems (Schneider et al. 2014). The tropical rain belt represents the ascending branches of both the Hadley cell and Walker cell. Our sensitivity experiments show that TA SST biases modify the surface energy balance in such a way that the ITCZ migrates towards the southern hemisphere, which is untruly simulated too warm. This finding matches common mean-state precipitation biases in coupled GCMs that also tend to place the ITCZ too far south (Richter et al. 2012a). Furthermore, the reversal of the equatorial Atlantic SST gradient forced by the bias pattern causes a weakening of equatorial easterlies of similar amplitude as simulated in coupled model integrations. The reduction of zonal winds along the equator drives the weakening of the Atlantic Walker circulation. The slow-down of the zonal overturning circulation comes along with a shift of the annual-mean precipitation maximum from the west to the east. However, our experimental setup does not allow for an analysis of what comes first. Do SST biases in the TA lead to the westerly wind bias, first, and wrong winds cause the precipitation changes, or, do precipitation changes lead the circulation changes? Answering this question would guide us to a better understanding of ITCZ biases in GCMs.

With our analysis of the moisture budget equation we show that changes in the tropical hydrological cycle are mainly dynamically driven and, by that, follow a "warmerget-wetter" pattern (Huang et al. 2013) on annual and seasonal mean time-scales. In contrast to the study of Huang et al. (2013), we cannot identify a "wet-get-wetter" mechanism on intraseasonal time-scales. However, in their study they investigate precipitation changes under global warming which leads to positive SST anomalies zonally more homogeneously with small variance in time, while our bias pattern shows high zonal asymmetry as well as substantial seasonal variability.

Intercomparing all sensitivity experiments emphasizes the importance of the spatial and temporal variability of TA biases for the simulated atmospheric response. With regard to a detailed analysis of the quantitative impact of SST biases on processes within the atmosphere, both BIAS_am and BIAS_mp do not serve as appropriate simplifications of the fully comprehensive bias pattern. Instead, determining the contribution of SST biases to mean-state biases in AOGCMs depends on the monthly-varying pattern used in BIAS_mm. This is especially important for the analysis of seasonal time-scale climate, as our analysis of seasonal rainfall shows (Figs. 10 and 11).

We find that considering the seasonal cycle of positive TA SST biases (BIAS_mp) is more important for reproducing the anomalous seasonal migration of the oceanic ITCZ that is simulated in BIAS_mm, than considering the presence of cold biases in the tropical Atlantic without a seasonal cycle (BIAS_am) (Figs. 8 and 9). In the annual mean, the forcing in experiment BIAS_am results in an overestimation of precipitation change, while it is slightly underestimated in BIAS_mp.

Even though sensitivity experiments BIAS_mp and BIAS_am cause quantitatively different precipitation and circulation changes, both of them help to develop a better understanding of the atmospheric response to the fully comprehensive SST bias pattern. In the eastern basin, BIAS_mp produces already changes in tropical rainfall very similar to BIAS_mm. However, the intensity of precipitation change is not captured when not considering negative biases in the pattern. Substantial drying over the South American continent is only simulated when considering cold biases in the forcing pattern. This highlights the role of negative biases in the western and northern TA. Cold biases play a primary role for the decrease of Brazilian rainfall. Furthermore, these negative SST biases act as essential amplifier of anomalous large-scale meridional, interhemispheric and zonal, near-equatorial SST gradients introduced by positive biases. These amplifications increase the slow-down of the Atlantic Walker circulation as well as the southward shift of the oceanic ITCZ which causes an amplification of the atmospheric response. Overall negative biases are not minor important than positive biases, because they contribute significantly to the simulated atmospheric response by amplifying anomalous SST gradients in the tropical Atlantic region and controlling the dry bias over the western Atlantic and Brazil. This finding is supported by sensitivity experiment BIAS_am that imposes too intense TA negative biases on seasonal scales, and by that leads to an overestimation of regional Atlantic circulation and precipitation changes.

Our approach to quantify the contribution of SST biases to other mean-state biases (e.g. wind, precipitation) lacks the ocean-atmosphere interaction, which definitely plays an important role in maintaining and reinforcing or damping coupled GCM biases. This limitation might explain to some part why coupled model mean-state biases cannot be fully reproduced by our sensitivity study. For example, our 


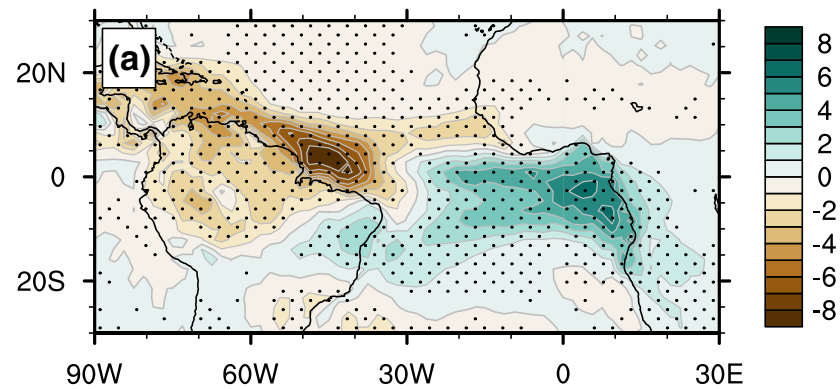

Fig. 12 BIAS $+2 \mathrm{~K}$ shows a very similar structure of annual-mean precipitation response as BIAS_mm (Fig. 3). The precipitation response under global warming differs only over the western Atlantic and South America by maximum $1 \mathrm{~mm} /$ day. a Annual-mean precipitation difference BIAS $+2 \mathrm{~K}-\mathrm{CTL}$, b difference between the

sensitivity experiments do not fully reproduce the substantial positive precipitation bias along the Coast of Guinea. However, the main structure of MPI-ESM mean-state precipitation and wind biases is fairly met. This shows that mean-state biases across the Atlantic basin and adjacent continents are mainly regionally forced by TA SST biases. Furthermore, because we can reproduce coupled model mean-state biases with our idealized experiments using climatological boundary conditions, interannual variability does not play a key role in their maintenance.

Main deficit in our experiments is that the model ECHAM6 already simulates considerable wind and precipitation biases when forced with observed SSTs and SICs (Hagemann et al. 2013; Siongco et al. 2014). In our study we have not argued these shortcomings but simply used the control experiment as a reference state for our analyses. The lack of understanding mechanisms leading to initial biases in the atmospheric circulation model however does not allow for drawing a direct causal relationship between simulated precipitation and circulation change, and TA SST biases in the coupled MPI-ESM.

Because one important aspect of GCMs is the projection of future climate, we rerun experiments CTL and BIAS $\mathrm{mm}$ after globally increasing SST boundary conditions by $2 \mathrm{~K}$. This very idealized scenario of climate change shows that the precipitation response to TA SST biases remains unchanged under global warming, assuming that the meanstate SST biases stay the same (Fig. 12). This is an important result because it allows the transfer of our main findings to climate simulations of the future, leading to a better interpretation of future climate change. However this result should be regarded with caution. Experiments of this study reveal high sensitivity of the climate simulation to the seasonal cycle of the TA bias pattern. Already small changes in the seasonality of the bias pattern under global warming, not considered in our idealized scenario, might cause a substantial different result.

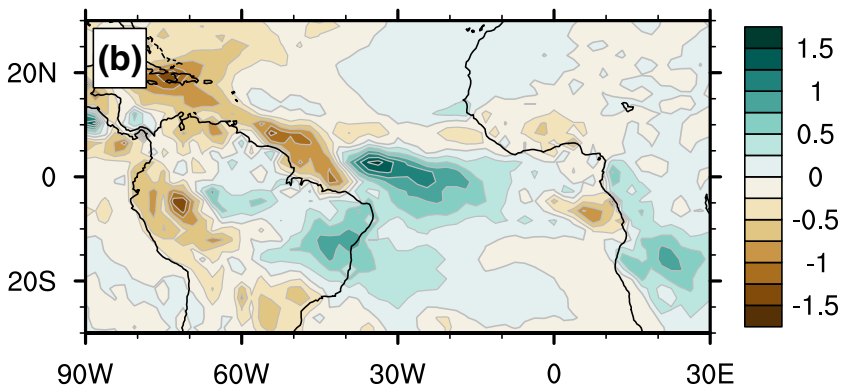

annual-mean precipitation changes in the global warming scenario $(\mathrm{BIAS}+2 \mathrm{~K})$ and the historical experiment (BIAS_mm). All values are in $\mathrm{mm} / \mathrm{day}$. Dotted areas in the right panel indicate differences statistically significant at the $95 \%$ confidence level

While we focused our study on the impact of tropical Atlantic SST biases on the Atlantic sector and adjacent landmasses it is important to mention that statistically significant changes in atmospheric circulation and precipitation are not confined to this region. Substantial influences can also be found on remote regions, such as the extratropics and the Indian basin. This will be addressed in another study.

Acknowledgements This work was done in the frame of the internal MPI-M project Tropical VIBES and parts of the work have been funded by the German Federal Ministry of Education and Research (BMBF) under the project MiKlip (FKZ: 01LP1158A). We would like to thank Angela Cheska Siongco for the internal review of this study. Furthermore, we acknowledge the German Climate Computing Center (DKRZ) for providing the computer hardware for our model experiments. NCEP Reanalysis data provided by the NOAA/OAR/ESRL PSD, Boulder, Colorado, USA, from their Web site at http://www. esrl.noaa.gov/psd/. Primary data and scripts used in the analysis and other supplementary information that may be useful in reproducing the authors' work are archived by the Max Planck Institute for Meteorology and can be obtained by contacting publications@mpimet.mpg.de. Open access funding provided by Max Planck Society.

Open Access This article is distributed under the terms of the Creative Commons Attribution 4.0 International License (http://creativecommons.org/licenses/by/4.0/), which permits unrestricted use, distribution, and reproduction in any medium, provided you give appropriate credit to the original author(s) and the source, provide a link to the Creative Commons license, and indicate if changes were made.

\section{References}

Adler RF, Huffman GJ, Chang A, Ferraro R, Xie P-P, Janowiak J, Rudolf B, Schneider U, Curtis S, Bolvin D, Gruber A, Susskind J, Arkin P, Nelkin E (2003) The version-2 global precipitation climatology project (GPCP) monthly precipitation analysis (1979-present). J. Hydrometeor 4(6): 1147-1167

Ashfaq M, Skinner CB, Diffenbaugh NS (2010) Influence of SST biases on future climate change projections. Clim Dyn 36(7-8):1303-1319 
Borges APD, Barfus K, Weiss H, Bernhofer C (2014) Trend analysis and uncertainties of mean surface air temperature, precipitation and extreme indices in CMIP3 GCMs in Distrito Federal, Brazil. Environ Earth Sci 72(12):4817-4833. doi:10.1007/ s12665-014-3301-y

Davey M, Huddleston M, Sperber K, Braconnot P, Bryan F, Chen D, Colman R, Cooper C, Cubasch U, Delecluse P, DeWitt D, Fairhead L, Flato G, Gordon C, Hogan T, Ji M, Kimoto M, Kitoh A, Knutson T, Latif M, Le Treut H, Li T, Manabe S, Mechoso C, Meehl G, Power S, Roeckner E, Terray L, Vintzileos A, Voss R, Wang B, Washington W, Yoshikawa I, Yu J, Yukimoto S, Zebiak S (2002) STOIC: a study of coupled model climatology and variability in tropical ocean regions. Clim Dyn 18(5):403-420

DeWitt DG (2005) Diagnosis of the tropical Atlantic near-equatorial SST bias in a directly coupled atmosphere-ocean general circulation model. Geophys Res Lett 32:L01703

Druyan LM (2011) Studies of 21st-century precipitation trends over West Africa. Int J Climatol 31(10):1415-1424

Fiorino M (2000) AMIP II sea surface temperature and sea ice concentration observations. http://www-pcmdi.llnl.gov/projects/ amip/AMIP2EXPDSN/BCS_OBS/amip2_bcs.htm

Fontaine B, Janicot S (1996) Sea surface temperature fields associated with West African rainfall anomaly types. J Clim 9(11):2935-2940

Giorgetta MA, Jungclaus J, Reick CH, Legutke S, Bader J, Bttinger M, Brovkin V, Crueger T, Esch M, Fieg K, Glushak K, Gayler V, Haak H, Hollweg H-D, Ilyina T, Kinne S, Kornblueh L, Matei D, Mauritsen T, Mikolajewicz U, Mueller W, Notz D, Pithan F, Raddatz T, Rast S, Redler R, Roeckner E, Schmidt H, Schnur R, Segschneider J, Six KD, Stockhause M, Timmreck C, Wegner J, Widmann H, Wieners K-H, Claussen M, Marotzke J, Stevens B (2013) Climate and carbon cycle changes from 1850 to 2100 in MPI-ESM simulations for the coupled model intercomparison project phase 5. J Adv Model Earth Syst 5(3):572-597

Hagemann S, Loew A, Andersson A (2013) Combined evaluation of MPI-ESM land surface water and energy fluxes. J Adv Model Earth Syst 5(2):259-286

Held IM, Soden BJ (2006) Robust responses of the hydrological cycle to global warming. J Clim 19(21):5686-5699

Huang P, Xie S-P, Hu K, Huang G, Huang R (2013) Patterns of the seasonal response of tropical rainfall to global warming. Nat Geosci 6(5):357-361

James IN (1994) Introduction to circulating atmospheres. Cambridge University Press, Cambridge

Kanamitsu M, Ebisuzaki W, Woollen J, Yang S-K, Hnilo JJ, Fiorino M, Potter GL (2002) NCEP-DOE AMIP-II reanalysis (R-2). Bull Am Meteorol Soc 83(11):1631-1643

Kucharski F, Bracco A, Yoo JH, Molteni F (2008) Atlantic forced component of the Indian monsoon interannual variability. Geophys Res Lett 35(4):L04706

Murakami H, Hsu P-C, Arakawa O, Li T (2014) Influence of model biases on projected future changes in tropical cyclone frequency of occurrence. J Clim 27:2159-2181

Pomposi C, Kushnir Y, Giannini A (2014) Moisture budget analysis of SSTdriven decadal Sahel precipitation variability in the twentieth century. Clim Dyn 44:3303

Richter I (2015) Climate model biases in the eastern tropical oceans: causes, impacts and ways forward. WIREs Clim Change $6: 345-358$
Richter I, Xie S-P (2008) On the origin of equatorial Atlantic biases in coupled general circulation models. Clim Dyn 31(5):587-598

Richter I, Xie SP, Behera SK, Doi T, Masumoto Y (2012a) Equatorial Atlantic variability and its relation to mean state biases in CMIP5. Clim Dyn 42(1-2):171-188

Richter I, Xie S-P, Wittenberg AT, Masumoto Y (2012b) Tropical Atlantic biases and their relation to surface wind stress and terrestrial precipitation. Clim Dyn 38:985-1001

Ryu J-H, Hayhoe K (2014) Understanding the sources of Caribbean precipitation biases in CMIP3 and CMIP5 simulations. Clim Dyn 42(11-12):3233-3252

Saini R, Wang G, Yu M, Kim J (2015) Comparison of RCM and GCM projections of boreal summer precipitation over Africa. J Geophys Res Atmos 120(9):3679-3699

Sasaki W, Doi T, Richards K, Masumoto Y (2014) Impact of the equatorial Atlantic sea surface temperature on the tropical Pacific in a CGCM. Clim Dyn 43(9-10):2539-2552

Schneider T, Bischoff T, Haug GH (2014) Migrations and dynamics of the intertropical convergence zone. Nature 513(7516):45-53

Siongco AC, Hohenegger C, Stevens B (2014) The Atlantic ITCZ bias in CMIP5 models. Clim Dyn 45(5-6):1169-1180. doi:10.1007/ s00382-014-2366-3

Stevens B, Giorgetta M, Esch M, Mauritsen T, Crueger T, Rast S, Salzmann M, Schmidt H, Bader J, Block K, Brokopf R, Fast I, Kinne S, Kornblueh L, Lohmann U, Pincus R, Reichler T, Roeckner E (2013) Atmospheric component of the MPI-M earth system model: ECHAM6. J Adv Model Earth Syst 5(2):146-172

Taylor KE, Williamson D, Zwiers F (2000). The sea surface temperature and sea-ice concentration boundary conditions for AMIP II simulations. Technical report, Program for Climate Model Diagnosis and Intercomparison Lawrence Livermore National Laboratory Livermore

Toniazzo T, Woolnough S (2014) Development of warm SST errors in the southern tropical Atlantic in CMIP5 decadal hindcasts. Clim Dyn 43(11):2889-2913

Trenberth KE, Guillemot CJ (1995) Evaluation of the global atmospheric moisture budget as seen from analyses. J Clim 8(9):2255-2272

Voldoire A, Claudon M, Caniaux G, Giordani H, Roehrig R (2014) Are atmospheric biases responsible for the tropical Atlantic SST biases in the CNRM-CM5 coupled model? Clim Dyn 43(11):2963-2984

Wahl S, Latif M, Park W, Keenlyside N (2011) On the tropical Atlantic SST warm bias in the Kiel climate model. Clim Dyn 36:1303-1319

Wang H, Fu R (2002) Cross-equatorial flow and seasonal cycle of precipitation over South America. J Clim 15(13):1591

Xu Z, Chang P, Richter I, Kim W, Tang G (2014) Diagnosing southeast tropical Atlantic SST and ocean circulation biases in the CMIP5 ensemble. Clim Dyn 43(11):3123-3145

Yin L, Fu R, Shevliakova E, Dickinson RE (2013) How well can CMIP5 simulate precipitation and its controlling processes over tropical South America? Clim Dyn 41(11-12):3127-3143. doi:10.1007/s00382-012-1582-y

Yoon J-H, Zeng N (2010) An Atlantic influence on Amazon rainfall. Clim Dyn 34(2-3):249-264 